\title{
Diel feeding rhythm of copepod size-fractions from Coliumo Bay, Central Chile*
}

\author{
DANILO CALLIARI ${ }^{1}$ and TARSICIO ANTEZANA ${ }^{2}$ \\ ${ }^{1}$ Sección Oceanografía, Universidad de la República. CP 11400 Montevideo, Uruguay. E-mail: dcalliar@fcien.edu.uy \\ ${ }^{2}$ Departmento de Oceanografía, Universidad de Concepción, Concepción, Chile. E-mail: antezana@udec.cl
}

\begin{abstract}
SUMMARY: The feeding behaviour of the size fractionated copepod assemblage was studied over a diel cycle in Coliumo Bay. In this shallow environment the photic layer reached the bottom and salinity, temperature, and food availability were fairly homogeneous throughout the water column. All four size-fractions $(250-500 \mu \mathrm{m}, 500-1000 \mu \mathrm{m}, 1000-2000 \mu \mathrm{m}$, $>2000 \mu \mathrm{m}$ ) showed a period of high feeding activity during the night and low feeding activity during the day. The persistence of nocturnal feeding in the presence of high food concentration over the 24-h cycle is interpreted as a predator avoidance strategy: empty guts by day make copepods less conspicuous to their visual daytime predators.
\end{abstract}

Key words: zooplankton, copepods, size-fractions, feeding rhythms, Chile.

\section{INTRODUCTION}

The vertical migration of zooplankton between deeper layers during the day and shallow layers at night is generally thought to occur when the water column is stratified into a shallow, lighted, food-rich layer and a deep, dark, oligotrophic layer. Under such conditions, the coupling of nocturnal feeding (NF) and diel vertical migration (DVM) would permit surface feeding at night when exposure to visual predators there is minimized (Gauld, 1953; Zaret and Suffern, 1976; Ohman et al., 1983; Verity and Smetaceck, 1996). A question arises in the field for shallow areas where zooplankton are unable to migrate out of surface area by day (to avoid predators). In such areas, will NF persist in spite of the inability to migrate by day, and in spite of persis-

\footnotetext{
*Received September 10, 1999. Accepted February 13, 2001.
}

tently available food? or will zooplankton feed continuously when food is available to make fastest use of available resources?. The results of studies addressed to answer these questions would give an indication of the importance of the pressures exerted on zooplankton, be they either food limitations or predation.

The typical Spring conditions of Coliumo Bay (36 $32^{\prime}$ ' S, 72 $57^{\circ}$ 'W, Fig. 1) provided an opportunity to analyze in situ the coupling between diel feeding and food availability in the absence of large scale diel vertical migration. In a shallow environment with a well mixed water column and high food concentration, the feeding activity of copepods was studied over a 24-hr cycle. The copepod community was fractionated in four size categories since metabolic rates and the extent of vertical migration are positively associated with size (Steele and Frost 1977; Hu, 1978; Cyr and Pace, 1993). 


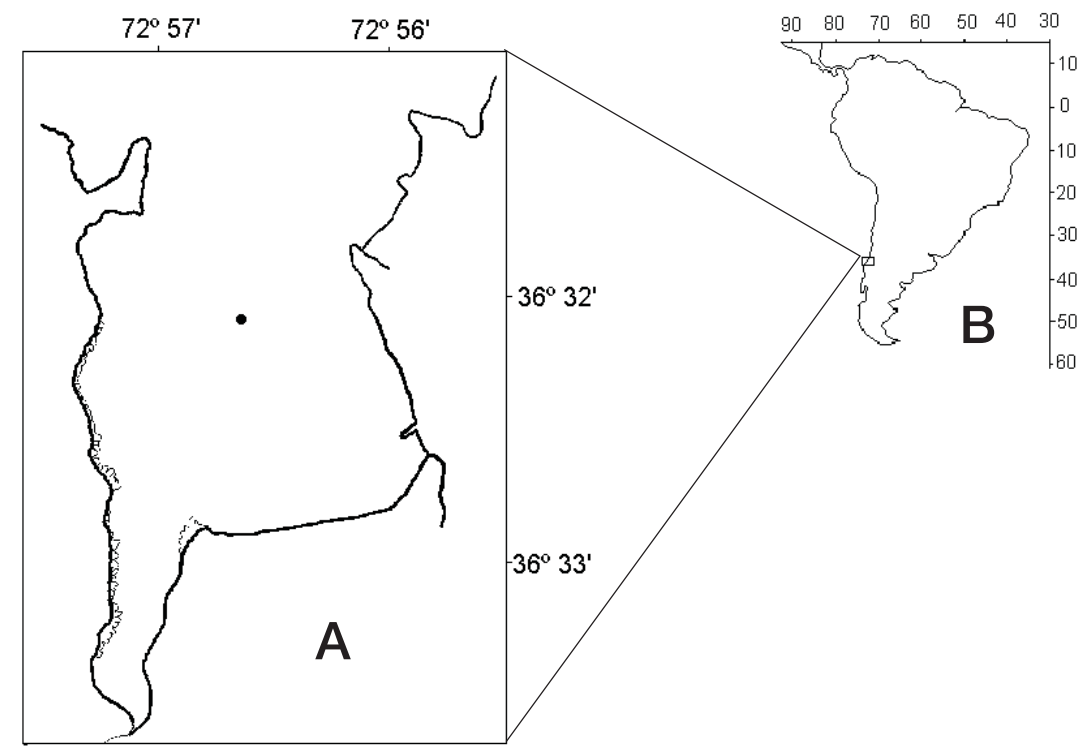

FIG. 1. - A. Map of Coliumo Bay. The black dot indicates the sampling station. B. Location of the study site in a general scale (South America).

\section{METHODS}

A sampling station was situated near the center of the Bay, where the water column is $c a .10 \mathrm{~m}$ deep. Zooplankton collections were carried out at 3-h intervals over a 24-h cycle on board the R/V KayKay on November 4 and 5, 1996. A bongo net $35 \mathrm{~cm}$ mouth diameter and $250 \mu \mathrm{m}$ mesh was obliquely towed from bottom to surface, slowly (0.2-0.5 knots) and quickly ( $c a .5 \mathrm{~min}$ ) to minimize stress to zooplankters. Immediately after the tow, the sample was mixed with carbon dioxide saturated water in equal parts in order to anaesthetize the organisms and prevent the loss of gut contents (Cervetto et al., 1993). Samples were then quickly and gently filtered through a battery of sieves of 200, 500, 1000 and $2000 \mu \mathrm{m}$. Resulting size-fractions were placed in a dark and cold $\left(0^{\circ} \mathrm{C}\right)$ insulated thermal box for $c a .1 \mathrm{~h}$ before laboratory analysis.

The zooplankton assemblage of Coliumo Bay and adjacent waters is strongly dominated by copepods (Arcos, 1975; Bernal et al., 1985; Peterson et al., 1988, Calliari 1999) of which the most abundant are: Calanus chilensis, Calanus australis, Calanoides patagoniensis, Centropages brachiatus and Rhincalanus nasutus in the two larger size-fractions (1000 - $2000 \mu \mathrm{m}$ and $>2000 \mu \mathrm{m})$, and Acartia tonsa, Paracalanus parvus, Oithona spp, Oncaea spp and copepodites in the two smaller size-fractions $(250-1000 \mu \mathrm{m})$.

Temperature and salinity measurements were taken every $6 \mathrm{~h}$ using a CTD (Sensordata 202).
Water samples for chlorophyll $a(\operatorname{chl} a)$ determination were collected at 12-h intervals and at $0,2,5$ and $8 \mathrm{~m}$ with a Niskin bottle. Chl $a$ concentration was estimated following Holm-Hansen et al. (1965) from $50 \mathrm{ml}$ sea water sub samples filtered on GF/F $(0.7 \mu \mathrm{m})$ filters. Pigments were extracted in $90 \%$ acetone and fluorescence was measured before and after acidification in a Turner Designs 10-005 R fluorometer. Light intensity in the water column was measured (Li-Cor, Li-193 sensor) (at 16:00 and 18:45) to estimate the extinction coefficient (k) and the depth of the photic layer.

Chl $a$-eq gut content in zooplankton was estimated following Mackas and Bohrer (1976) and used as an index of feeding activity. Given that zooplankton samples from Coliumo Bay are overwhelmingly comprised of copepods, only these organisms were sorted out for feeding estimates; and so all subsequent considerations refer to copepods. Zooplankton samples were processed as follows: 30 or more copepods from the smaller size-fractions and 15 from the larger ones were sorted out under a dissecting microscope and dim light, and transferred to a $90 \%$ acetone solution for pigment extraction during $12 \mathrm{~h}$ at $-20^{\circ} \mathrm{C}$ in darkness. Fluorescence was then measured with a Turner Designs fluorometer before and after acidification. Total gut pigment values (chl $a$-eq) were corrected by adding $33 \%$ to compensate for losses of fluorescence (Dam and Peterson, 1988; Lopez et al., 1988; Downs, 1989; Cervetto et al., 1993; Peterson and Dam, 1996) and by subtracting the background fluorescence of animal tissues (estimated from cope- 
pods representative of Coliumo Bay assemblage starved for $24 \mathrm{~h}$ in GF/F filtered sea water). Background fluorescence values were less than $0.1 \mathrm{ng} \mathrm{chl}$ $a$-eq. ind. ${ }^{-1}$ for smaller species $A$. tonsa and P. parvus, and around $0.25 \mathrm{ng}$ chl $a$-eq. ind. ${ }^{-1}$ for larger species Calanus spp and $C$. brachiatus.

\section{RESULTS AND DISCUSSION}

Temperature and salinity were quite homogeneous through the water column during the study period (Fig. 2a,b). The light extintion coefficient $\mathrm{k}$ estimated from the equation (Parsons et al. 1984):

$$
\mathrm{I}_{\mathrm{z}}=\mathrm{I}_{0} \cdot \mathrm{e}^{-\mathrm{k} \cdot \mathrm{z}}
$$
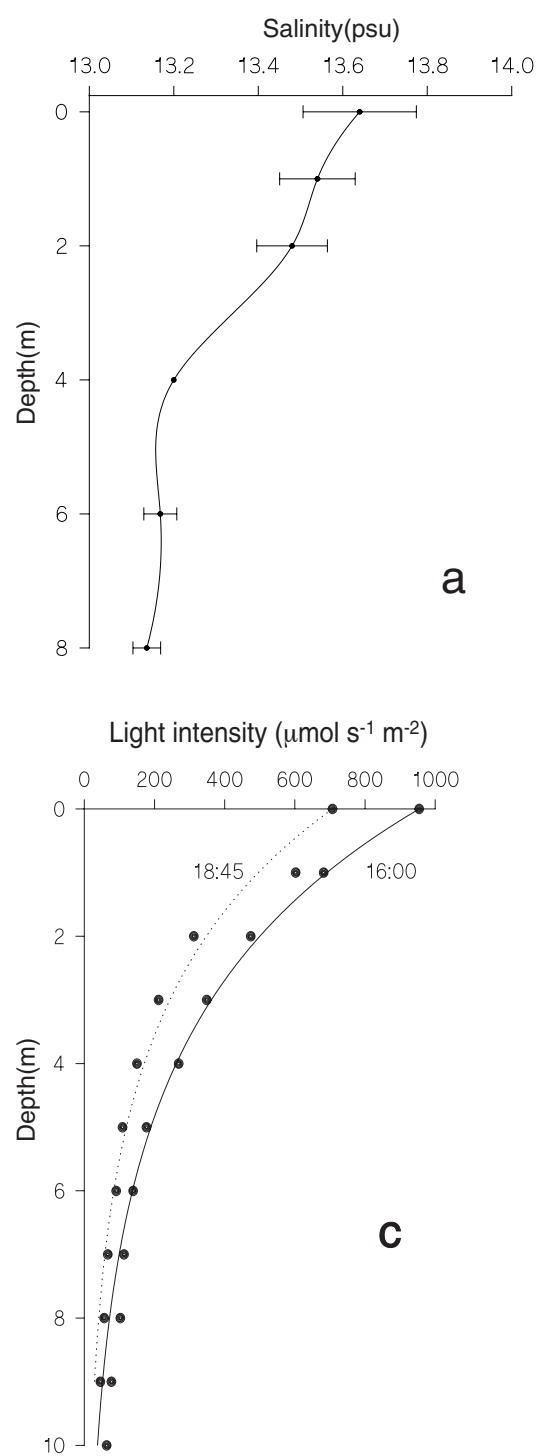

where $I_{o}$ is light intensity at the surface, $z$ is the depth and $\mathrm{I}_{\mathrm{z}}$ is light intensity at depth $\mathrm{z}$, indicated that the photic depth was greater than the water column depth. The percentage of incident light that reached the depth of $10 \mathrm{~m}$ at 16:00 and 18:45 was $4 \%\left(\mathrm{k}=0.323 \mathrm{~m}^{-1}, \mathrm{r}^{2}=0.99\right.$, photic depth $\left.14.4 \mathrm{~m}\right)$ and $3 \%\left(\mathrm{k}=0.354 \mathrm{~m}^{-1}, \mathrm{r}^{2}=0.97\right.$, photic depth $\left.13.2 \mathrm{~m}\right)$, respectively (Fig. 2c). Chl $a$ vertical distribution was highly variable and fairly homogeneous too, with a smooth peak at around $5 \mathrm{~m}$ depth (Fig. 2d).

Gut pigment content of the larger size fractions (1000-2000 $\mu \mathrm{m}$ and $>2000 \mu \mathrm{m})$ ranged between 0.5 and $11.7 \mathrm{ng}$ chl $a$-eq. ind. ${ }^{-1}$. Such values are close to those obtained by Peterson et al. (1988) for Centropages brachiatus $(0.14-14.20 \mathrm{ng}$ chl $a$-eq. ind.' ${ }^{1}$ ) and for Calanus chilensis (0.21 - $9.50 \mathrm{ng} \mathrm{chl}$ a-eq. ind..$^{-1}$ ) outside Coliumo Bay. Our gut content esti-
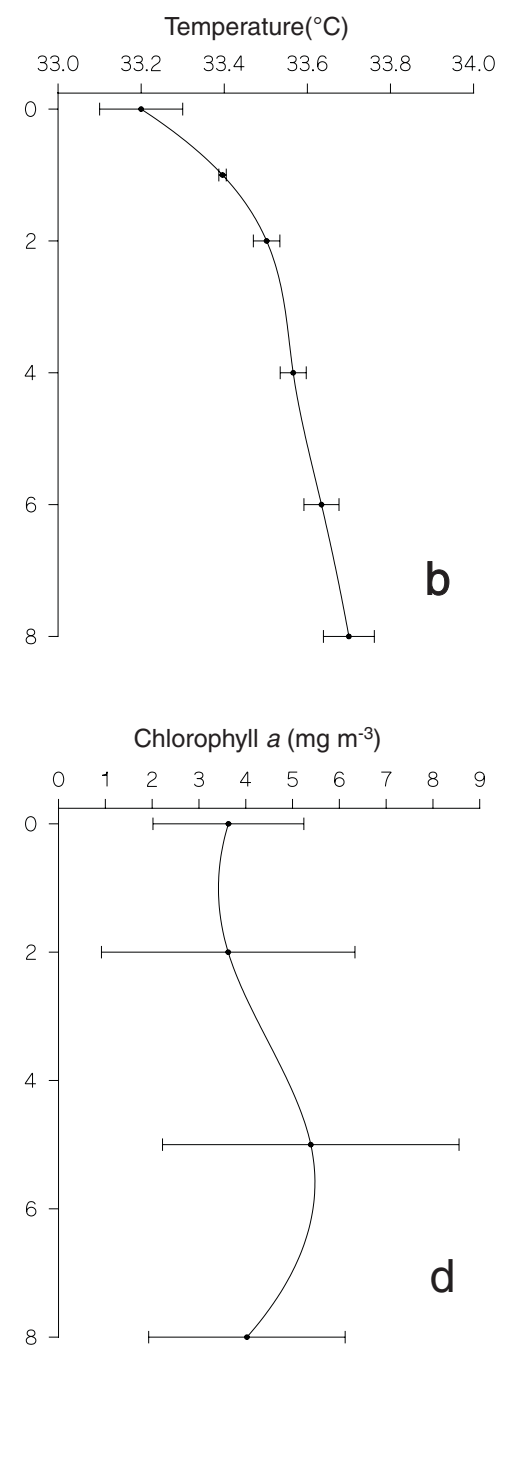

FIG. 2. - Vertical profiles of salinity (a), temperature (b), light penetration through the water column (c) and chlorophyll $a$ (d) recorded in Coliumo Bay during the diel study (November 1996). In a, b and d error bars are standard deviations. 

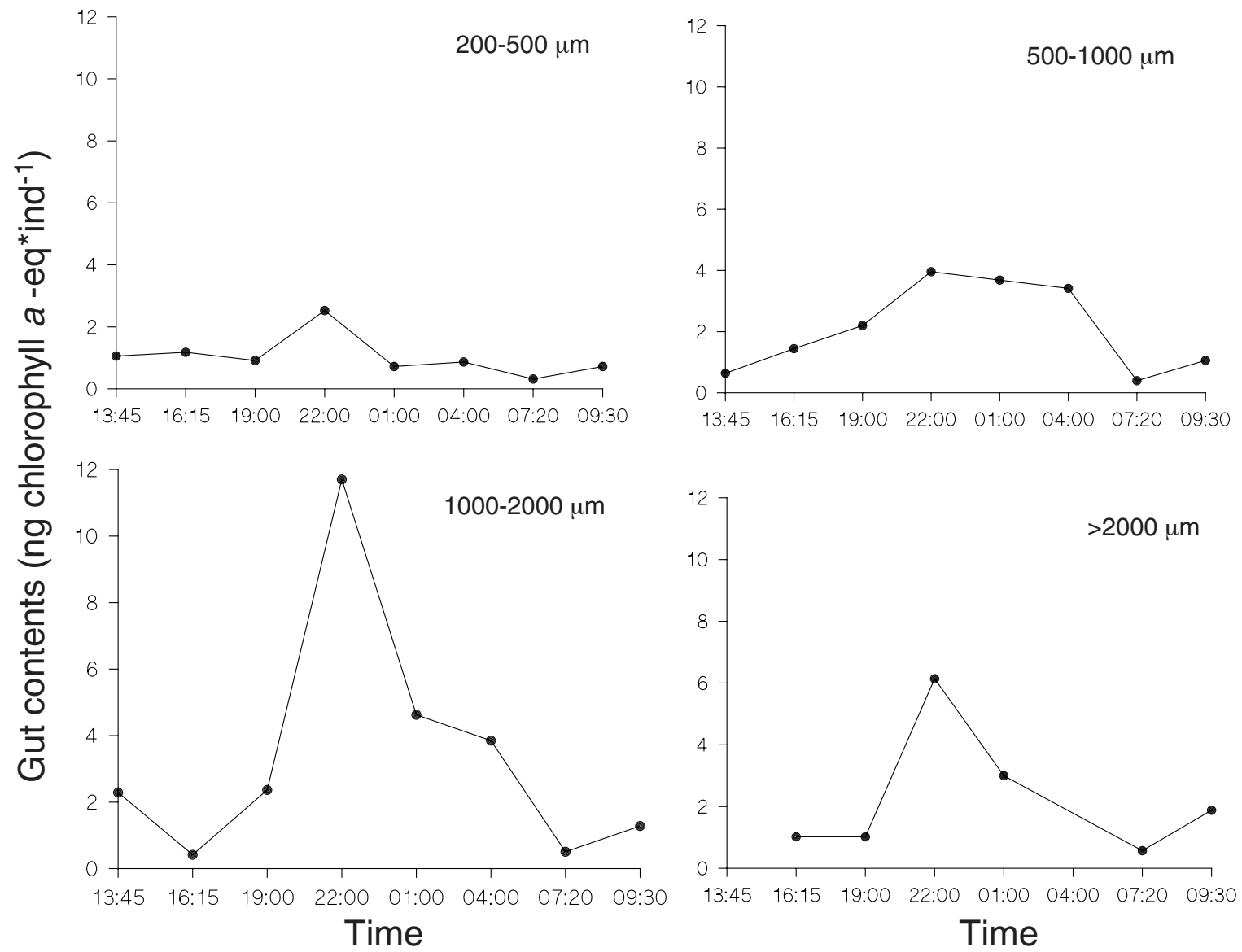

FIG. 3. - Gut contents of the four size-fractions of the copepods over a diel cycle.

mates for the larger size-fractions are also similar to those of Calanoides patagoniensis (0.5 - $5.5 \mathrm{ng} \mathrm{chl}$ $a$-eq. ind. $\left.^{-1}\right)$, but significantly lower than in $C$. chilensis (5 - 45 ng chl $a$-eq. ind. ${ }^{-1}$ ) in Concepción Bay (Castro et al., 1991). Gut contents varied between 0.3 and $4 \mathrm{ng}$ chl $a$-eq. ind. ${ }^{-1}$ for the smaller size-fractions (250-500 $\mu \mathrm{m}$ and 500-1000 $\mu \mathrm{m})$, which are similar to those obtained in vitro for $A$. tonsa (0.41-6.97 ng chl $a$-eq. ind..$^{-1}$; Durbin et al., 1990), and higher than those of Acartia spp in the Japan Sea ( 0.1 - $0.5 \mathrm{ng}$ chl $a$-eq. ind. ${ }^{-1}$, Checkley et al., 1992).

All size-fractions showed reduced feeding during the day and high feeding activity during the night hours, with a peak between 22:00 and 4:00 (Fig. 3), except for the smaller size-fraction $(250-500 \mu \mathrm{m})$ which showed a more restricted peak around 22:00. The observed feeding rhythm was consistent with studies that describe circadian feeding rhythms in several species (i.e. Mackas and Bohrer, 1976; Baars and Oosterhuis, 1984; Durbin et al., 1990; Castro et al., 1991; Checkley et al., 1992; Cervetto et al., 1993), and also agrees with the persistence of circa- dian feeding rhythms in copepods under non limiting food supply or constant illumination (Petipa, 1958 fide Stearns, 1986; Mayzaud et al., 1984; Stearns, 1986; Dagg et al., 1989).

In all these cases, NF seems to be the rule. The only exception seems to occur when limiting food conditions either alter or suppress the diel feeding rhythms (Daro, 1985; Gliwicz and Pijanowska, 1988). For example, Acartia clausi displayed flexible feeding, with maximum gut content in either day or night samples according to highest ambient food concentrations (Pagano and Saint-Jean, 1985 fide Cervetto et al. 1993). Other species like A. tonsa, though affected by ambient food concentration are primarily nocturnal feeders (Durbin et al., 1990; Cervetto et al., 1993). In the present study, the fact that NF persisted in the presence of abundant food suggests that, at least in Spring in Coliumo Bay, food was not the major concern, but that some other factor, namely predation, could be.

Feeding to zooplankton is costly in terms of predation risks incurred from non-visual predators (Gerritsen and Strickler, 1977; Kerfoot, 1982; Roth- 
schild and Osborn, 1988; Tiselius et al., 1997) and visual predators as well (Guiguere and Northcote, 1987). Tsuda et al. (1998) showed that visual predators fed at significantly higher rates on copepods with full guts than on copepods with empty guts. Then NF in itself, would be a strategy to reduce predation by visual predators in daylight hours. This strategy would emerge as a trade-off to reduce mortality at the cost of fasting during the day.

NF is usually associated with DVM, though most of the advantages attributed to both behaviors are hardly applicable in shallow mixed environments. In Coliumo Bay in Spring there are no energetic incentives to migrate vertically (Loose and Dawidowicz, 1994) because the temperature gradient is minimal and food is fairly homogeneous. Since currents are clockwise (Sobarzo, 1984), neither is there any incentive for migrating vertically into a layer for "hitch hiking" purposes (Hardy, 1956). In Spring, the photic layer reaches the bottom, so there is literally nowhere for zooplankton to go, nonetheless hide, so copepods remain in the photic zone, exposed to high food concentrations and predators. The persistence of NF for all size fractions is interpreted as an effective strategy by which to reduce predation by visual predators.

\section{ACKNOWLEDGEMENTS}

This research was funded by Dirección de Investigación, Universidad de Concepción (P.I. 97.112.041-6), the CIMAR-Fiordos Project, and a DAAD (Deutscher Akademischer Austauschdienst) scholarship to D. Calliari for postgraduate studies at Universidad de Concepción. We thank two anonymous reviewers for their comments and improvements of a version of the manuscript by Kristen Ray.

\section{REFERENCES}

Arcos, D.F. - 1975. Copépodos Calanoides de la Bahía Concepción, Chile. Conocimiento Sistemático y Variación estacional. Gayana, 32: 1-31.

Baars, M.A. and S.S. Oosterhuis. - 1984. Diurnal feeding rhythms in North Sea copepods measured by gut fluorescence, digestive enzyme activity and grazing on labelled food. Netherlands $J$. Sea Res., 18(1/2): 97-119.

Bernal, P., M. George-Nascimento, L. Vergara and V.A. Troncoso. - 1985. Patrones de variación espacial y temporal en una taxocenosis de copépodos de una bahía altamente productiva. Informe de proyecto D.I.U.C. 184/82. Pontificia Universidad Católica de Chile, Talcahuano. 26 pp.

Calliari, D. -1999. Modulación de la tasa de ingestión del zooplancton herbivoro por la microturbulencia. Tesis para optar al grado de Doctor en Oceanografía. Universidad de Concepción. 154 pp.
Castro, L.R., P.A. Bernal and H.E. González. - 1991. Vertical distribution of copepods and the Utilisation of the chlorophyll arich Layer within Concepcion Bay, Chile. Estuar Coast Shelf Sci., 32: 243-256.

Cervetto, G., R. Gaudy, M. Pagano, L. Saint-Jean, G. Verriopoulos, R. Arfi and M. Leveau. - 1993. Diel variations in Acartia tonsa feeding, respiration and egg production in a Mediterranean coastal lagoon. J. Plankton Res., 15(11): 1207-1228.

Chekley, D.M., M.J. Dagg and S. Uye. - 1992. Feeding, excretion and egg production by individuals and populations of the marine, planktonic copepods, Acartia spp and Centropages furcatus. J. Plankton Res., 14(1): 71-96.

Cyr, H. and M.L. Pace. - 1993. Allometric theory: Extrapolations from individuals to communities. Ecology, 74, 1234-1245.

Dagg, M.J., W. Frost and W.E. Walser. - 1989. Copepod diel migration, feeding and the vertical flux of phaeopigments. Limnol. Oceanogr., 34: 1062-1071.

Dam, H.G. and W.T. Peterson. - 1988. The effect of temperature on gut clearence rate constant of planktonic copepods. J. exp. mar. Biol. Ecol. 123: 1-14.

Daro, M.H. -1985. Feeding rhythms and vertical distribution of marine copepods. Bull. Mar. Sci., 37: 487-497.

Downs, J. -1989. Implication of the phaeopigments, carbon and nitrogen content of sinking particles for the origin of export production. $\mathrm{PhD}$ dissertation, Univ. of Washington, $196 \mathrm{pp}$.

Durbin, A.G., E.G. Durbin and E. Wlodarczyk. - 1990. Diel feeding behaviour in the marine copepod Acartia tonsa in relation to food availability. Mar. Ecol. Prog. Ser., 68: 23-45.

Gauld, D.T. -1953. Diurnal variations in the grazing of planktonic copepods. J. Mar. Biol. Assoc. UK, 31: 461-474.

Gerritsen, J. and J.R. Strickler. -1977. Encounter probabilities and community structure in zooplankton: a mathematical model. Fish. Res. Board Can., 34: 73-82.

Gliwicz, M.Z. and J. Pijanowska. - 1988. Effect of predation and resource depth distribution on vertical migration of zooplankton. Bull. Mar. Sci., 43(3): 695-709.

Guiguere, L.A. and T.G. Northcote. - 1987. Ingested prey increases risk of visual predation in transparent Chaoborus larvae. Oecologia, 73: 48-52.

Hardy, A.C. - 1956. The Open Sea, its Natural History: The World of Plankton. Collins, London, $335 \mathrm{pp}$. .

Holm-Hansen, O., C.J. Lorenzen, R.W. Holmes and J.D.H. Strickland. - 1965. Fluorometric determination of chlorophyll. $J$. Cons. Perm. Int. Explor. Mer., 30: 3-15.

Hu,V.J.H. - 1978. Relationships between vertical migration and diet in four species of euphausiids. Limnol. Oceanogr., 23, 296306.

Kerfoot, W.C. - 1982. A question of taste: Crypsis and warning coloration in freshwater zooplankton comunities. Ecology, 63: 538-554.

Lopez, M.D.G., M.E. Huntley and P.F. Sykes. - 1988. Pigment destruction rates by Calanus pacificus: impact on the estimation of water column fluxes. J. Plankton Res., 10: 715-734.

Loose, C.J. and P. Dawidowicz. - 1994. Trade-offs in diel vertical migration by zooplankton: the costs of predator avoidance. Ecology, 75(8): 2255-2263.

Mackas D. and R. Bohrer. - 1976. Fluorescence analysis of zooplankton gut contents and an investigation on diel feeding patterns. J. exp. mar. Biol. Ecol., 25: 77-85.

Mayzaud, O., P. Mayzaud, C. de la Bigne and P. Grohan. -1984. Diel changes in the particulate environment, feeding activity and digestive enzime concentration in neritic zooplankton. $J$. exp. mar. Biol. Ecol., 84: 15-35.

Ohman, M.D., B.W. Frost and E.B. Cohen. - 1983. Reverse diel vertical migration: an escape from invertebrate predators. Science, 220: 1404-1407.

Pagano, M. and L. Saint-Jean. - 1985. Primiéres donnes sur le nutrition d'Acartia clausi en Lagune Ebrié (Cóte d'Ivory) obtenues par des mesures de la fluorescence de broyats d'animaux. Hydrobiologia, 121: 83-95.

Parsons, T.R., M. Takahashi and B. Hargrave. - 1984. Biological oceanographic processes. Pergamon press $3^{\text {rd }}$ ed. $330 \mathrm{pp}$.

Peterson, W.T. and H. Dam. -1996. Pigment ingestion and egg production rates of the calanoid copepod Temora longicornis: implications for gut pigment loss and omnivory feeing. $J$. Plankton Res., 18(5): 855-861

Peterson W.T., D.F. Arcos, G.B. MacManus, H. Dam, T. Johnson and P. Tiselius. - 1988. The nearshore during coastal 
upwelling: Daily variability and coupling between primary and secondary production off central Chile. Prog. Oceanogr., 20: $1-40$.

Petipa, T.S. -1958 . The diurnal feeding rhythm of of the copepod crustacean Acartia clausi Giesbr. Dokl. Akad. Nauk SSSR, 129: 435-437.

Rothschild, B.J. and T.R. Osborn. - 1988. Small scale turbulence and plankton contact rates. J. Plankton Res., 10(3): 465-474.

Sobarzo, M. - 1984. Patrón general de circulación (en condiciones invernales) de Bahia Coliumo ( $36^{\circ} 32^{\prime} S$; $72^{\circ} 56^{\prime}$ W) Concepción, Chile. Tesis Univ. Concepción, $71 \mathrm{pp}$.

Stearns, D.E. - 1986. Copepod grazing behaviour in simulated natural light and its relation to nocturnal feeding. Mar. Ecol. Prog. Ser., 30: 65-76.

Steele, J.H. and Frost, B.W. - 1977. The structure of plankton communities. Trans. R. Soc., Lond., Ser. B, 280: 48-534.
Tiselius, P., P.R. Jonson, S. Kaartvedt, E.M. Olsen and T. Jørstad. - 1997. Effect of copepod foraging behavior on predation risk: An experimental study of the predatory copepod Pareuchaeta norvegica feeding on Acartia clausi and A. tonsa (Copepoda). Limnol. Oceanogr., 42(1): 164-170.

Tsuda, A., H. Saito and T. Hirose. - 1998. Effect of gut content on the vulnerability of copepods to visual predation. Limnol. Oceanogr., 43(8): 1944-1947.

Verity, P.G. and V. Smetacek. - 1996. Organism life cycles, predation, and the structure of marine pelagic ecosystems. Mar. Ecol. Prog. Ser., 130: 277-293.

Zaret, T.M. and J.S. Suffern. - 1976. Vertical migration in zooplankton as a predator avoidance mechanism. Limnol. Oceanogr., 21: 804-813.

Scient. ed.: R. Anadón 